\title{
InsP $_{3}$ Signaling in Apicomplexan Parasites
}

Celia R.S. Garcia ${ }^{1, *}$, Eduardo Alves ${ }^{2}$, Pedro H.S. Pereira ${ }^{1,2}$, Paula J. Bartlett ${ }^{3}$, Andrew P. Thomas ${ }^{3}$, Katsuhiko Mikoshiba ${ }^{4}$, Helmut Plattner ${ }^{5}$ and L. David Sibley ${ }^{6}$

\begin{abstract}
${ }^{I}$ Departamento de Fisiologia, Instituto de Biociencias, Universidade de São Paulo. Sao Paulo 05508-090, Brazil; ${ }^{2}$ Departamento de Parasitologia, Instituto de Ciências Biomédicas, Universidade de São Paulo. Sao Paulo 05508-000, Brazil; ${ }^{3}$ New Jersey Medical School, Rutgers, The State University of New Jersey, New Jersey, USA; ${ }^{4}$ Laboratory for Developmental Neurobiology, RIKEN Brain Science Institute, Wako, Saitama, Japan; ${ }^{5}$ Department of Biology, University of Konstanz, 78457 Konstanz, Germany; ${ }^{6}$ Department of Molecular Microbiology, Washington University Sch. Med., Saint Louis, USA
\end{abstract}

\section{A R T I C L E H IS T O R Y}

Received: September 01, 2016 Revised: October 20, 2016 Accepted: October 30, 2016 DOI: $10.2174 / 1568026617666170130121042$

\begin{abstract}
Background: Phosphoinositides (PIs) and their derivatives are essential cellular components that form the building blocks for cell membranes and regulate numerous cell functions. Specifically, the ability to generate myo-inositol 1,4,5-trisphosphate $\left(\mathrm{InsP}_{3}\right)$ via phospholipase $\mathrm{C}$ (PLC) dependent hydrolysis of phosphatidylinositol 4,5-bisphosphate $\left(\mathrm{PIP}_{2}\right)$ to InsP3 and diacylglycerol (DAG) initiates intracellular calcium signaling events representing a fundamental signaling mechanism dependent on PIs. InsP $\mathrm{I}_{3}$ produced by PI turnover as a second messenger causes intracellular calcium release, especially from endoplasmic reticulum, by binding to the $\operatorname{InsP}_{3}$ receptor $\left(\operatorname{Ins} \mathrm{P}_{3} \mathrm{R}\right)$. Various PIs and the enzymes, such as phosphatidylinositol synthase and phosphatidylinositol 4-kinase, necessary for their turnover have been characterized in Apicomplexa, a large phylum of mostly commensal organisms that also includes several clinically relevant parasites. However, $\mathrm{InsP}_{3} \mathrm{Rs}$ have not been identified in genomes of apicomplexans, despite evidence that these parasites produce $\mathrm{InsP}_{3}$ that mediates intracellular $\mathrm{Ca}^{2+}$ signaling.

Conclusion: Evidence to supporting $\mathrm{IP}_{3}$-dependent signaling cascades in apicomplexans suggests that they may harbor a primitive or non-canonical $\mathrm{InsP}_{3} \mathrm{R}$. Understanding these pathways may be informative about early branching eukaryotes, where such signaling pathways also diverge from animal systems, thus identifying potential novel and essential targets for therapeutic intervention.
\end{abstract}

Keywords: Calcium signaling, $\mathrm{InsP}_{3}$ signaling, Apicomplexan parasites, Phosphoinositides, Plasmodium.

\section{INTRODUCTION}

Phosphoinositides (PIs) and their derivatives are important for controlling a variety of vital cell functions including intracellular signaling cascades, regulated secretion, and cytoskeleton integrity [1]. The inositol containing phospholipids are abundant constituents of cell membranes of Archaea and all eukaryotes [2]. The importance of inositol signaling has been known for many years. However, the seminal discovery that ligation of cell surface receptors and PLC activity coupled to PI turnover and calcium release $[3,4]$ paved the way for the discovery of the secondary messengers InsP $\mathrm{P}_{3}$ and diacylglycerol (DAG) and the downstream signaling cascades regulated by their generation and metabolism. $\operatorname{InsP}_{3}$ formation depends on phospholipase C (PLC) that is activated by a variety of specific cell surface receptors. PLC cleaves phosphatidylinositol 4,5-bisphosphate $\left(\mathrm{PIP}_{2}\right)$, thus releasing soluble InsP ${ }_{3}[5,6]$. Pharmacological evidence supports $\mathrm{InsP}_{3}$ signaling in unicellular eukaryotes such as

*Address correspondence to this author at the Rua do Matão, travessa 14, n 321. Cidade Universitária, São Paulo, Brazil. - CEP 05508-090; Tel: +55 (11) 30917518; Fax: +55 (11) 30918095; E-mail: cgarcia@usp.br members of the phylum Apicomplexa, a diverse group that includes Plasmodium, Toxoplasma and Cryptosporidium. The mobilization of intracellular $\mathrm{Ca}^{2+}$ level by $\mathrm{InsP}_{3}$ in single cell pathogens was described in Trypanosoma, a Kinetoplastid member of the phylum Euglenozoa. Although the cell surface receptor mediated signaling cascades that lead to $\mathrm{InsP}_{3}$-dependent, and potentially DAG-dependent, signaling cascades have not been fully delineated, there is mounting evidence to suggest these pathways are operative in apicomplexans.

Interest in $\mathrm{Ca}^{2+}$ signaling in these parasites is motivated by a history of studies demonstrating the requirement of $\mathrm{Ca}^{2+}$ signaling for infection by apicomplexan parasites, as recently reviewed [7]. Elevation of intracellular calcium regulates secretion of adhesins from microneme organelles, as well as activating actin-myosin dependent motility. As described below, parasite pathways that recruit proteins sufficiently divergent from their mammalian hosts may be exploited for development of novel therapeutic interventions (Fig. 1).

Apicomplexans share many molecules pertinent to $\mathrm{Ca}^{2+}$ signaling with their closest relatives, the ciliates (phylum Ciliophora), despite these two groups being evolutionarily 


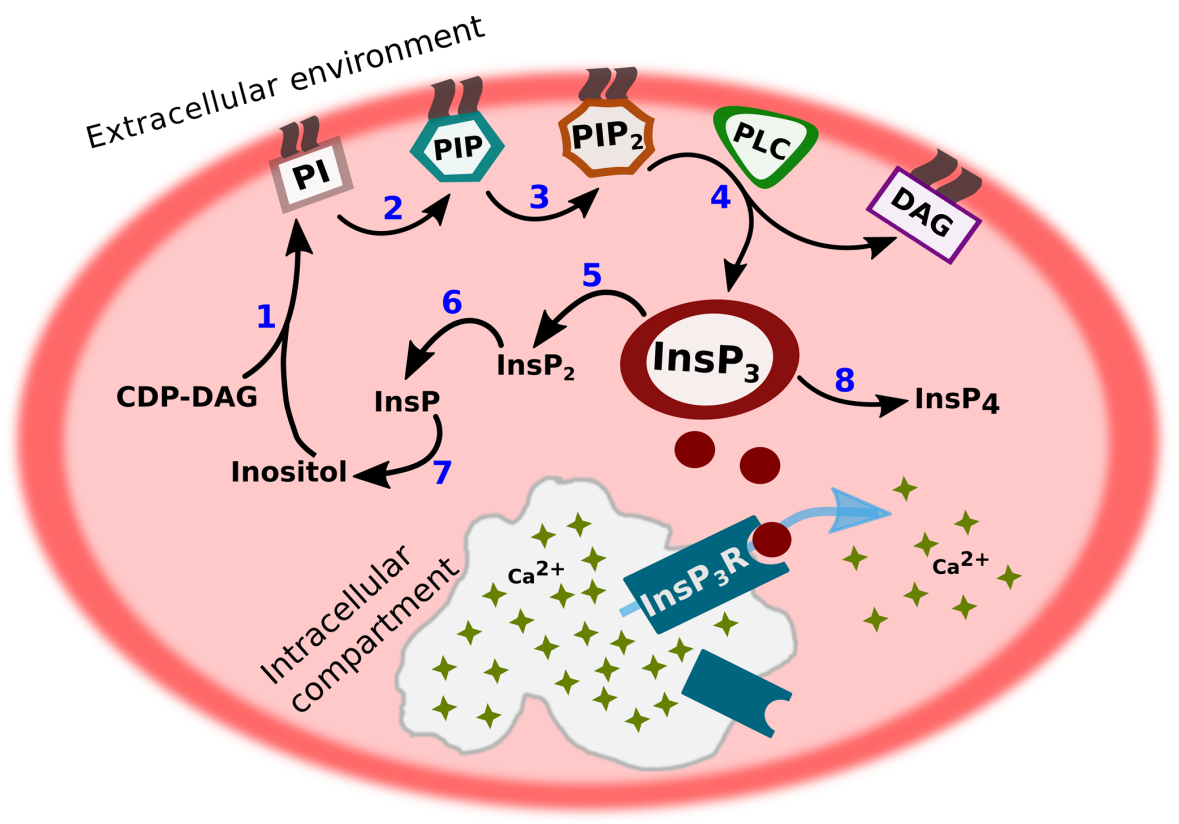

Fig. (1). Schematic representation of the myo-inositol 1,4,5-triphosphate $\left(\mathrm{InsP}_{3}\right)$ turnover and its function in intracellular $\mathrm{Ca}^{2+}$ release. Step 1 : Inositol incorporation into CDP-DAG (CDP = cytidine diphosphate DAG = diacylglycerol) catalyzed by phosphatidylinositol synthase generating phosphatidylinositol (PI). Step 2: Phosphorylation of PI by phosphatidylinositol 4-kinase forming phosphatidylinositol 4-phosphate (PIP). Step 3: Phosphorylation of PIP by phosphatidylinositol 4-phosphate 5-kinase forming phosphatidyl 4,5-bisphosphate (PIP 2 ). Step 4: $\mathrm{PIP}_{2}$ is cleaved by phospholipase C (PLC) generating a soluble molecule, inositol 1,4,5-trisphosphate (Ins $\mathrm{P}_{3}$ ), that is capable to bind to a Ins: $\mathrm{P}_{3}$ receptor $\left(\mathrm{InsP}_{3} \mathrm{R}\right)$ present in the membranes of intracellular compartments. InsP $\mathrm{P}_{3}$ binding temporarily opens the Ins $\mathrm{P}_{3} \mathrm{R}$ that acts as a Ca ${ }^{2+}$ release channel, so that $\mathrm{Ca}^{2+}$ can flow into the cytoplasm. The insoluble fraction formed by cleavage of PIP ${ }_{2}$ is diacylglycerol (DAG). Step 5: $\mathrm{Ins}_{3}$ is dephosphorylated by inositolpolyphosphate 5-phosphatase forming inositol 1,4-bisphosphate $\left(\operatorname{InsP}_{2}\right)$. $\mathrm{Step}$ : InsP $\mathrm{P}_{2}$ is desphosphorylated by inositol polyphosphate 1-phosphatase generating inositol 1-monophosphate (InsP). Step 7: Dephosphorylation of InsP to inositol by inositol monophosphatase. Step 8: phosphorylation of $\mathrm{InsP}_{3}$ by inositol 1,4,5-trisphosphate 3-kinase generating inositol 1,3,4,5tetrakisphosphate $\left(\mathrm{InsP}_{4}\right)$.

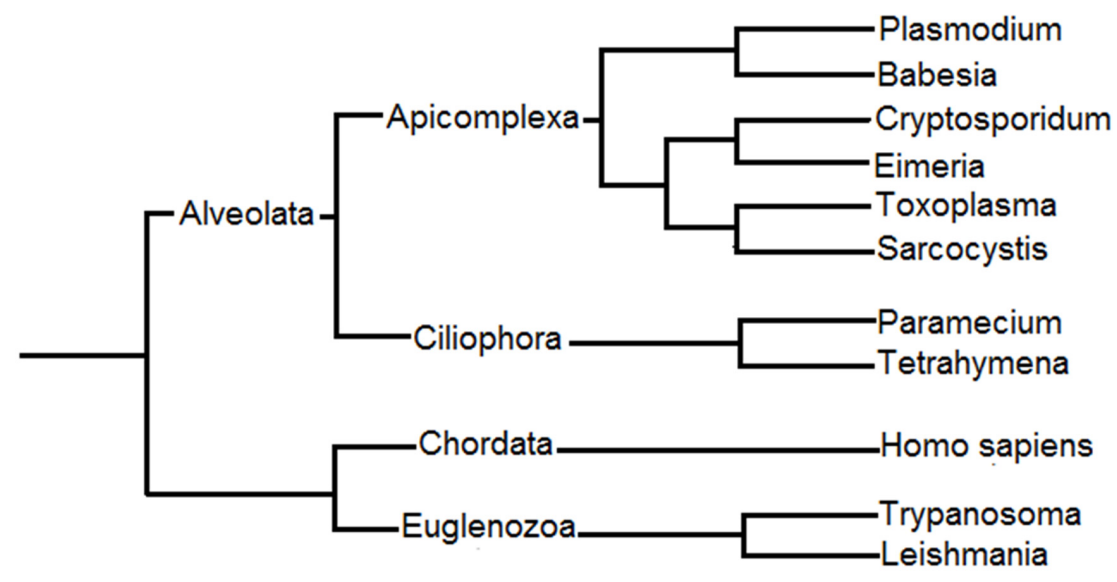

Fig. (2). Phylogenetic tree showing evolutionary relationships among organisms discussed in this review.

quite diverse [8]. Both groups are combined in the Alveolata, due to their endowment with subplasmalemmal flattened membranes, i.e. alveolar sacs in ciliates and inner membrane complex in apicomplexans. In ciliates, $\mathrm{Ca}^{2+}$ signaling mechanisms are known in some detail, including the molecular identity of intracellular $\mathrm{Ca}^{2+}$ channels involved in $\mathrm{Ca}^{2+}$ release from intracellular $\mathrm{Ca}^{2+}$ stores $[9,10]$. In contrast, identifying $\mathrm{Ca}^{2+}$-channels in apicomplexans such as Plasmodium and Toxoplasma has proved a major challenge. However, the recent development of transgenic parasites expressing genetically encoded sensors for detection of $\mathrm{Ca}^{2+}$ in $P$. falcipa- rum and $T$. gondii may reveal new aspects of $\mathrm{Ca}^{2+}$ signaling $[11,12]$ (Fig. 2).

\section{EVIDENCE OF INSP 3 TURNOVER AND INSP $_{3}$ - INDUCED $\mathrm{CA}^{2+}$ RELEASE IN APICOMPLEXA}

Inositol and inositol phospholipids have been described in most Archaea and eukaryotes indicating this system developed in a common ancestor of the Archaea kingdom approximately 2 billion years ago [2,13]. Inositol phospholipids (PI) are ubiquitous components of cell membranes, there is not a unique PI found only in apicomplexan. Table $\mathbf{1}$ 
Table 1. Occurrence of proteins important for the $\mathrm{InsP}_{3}$ signaling pathway in some model organisms. The corresponding genes were searched for in the databases of Plasmodium, Toxoplasma, Homo sapiens, Trypanosoma and Paramecium (PlasmoDB, ToxoDB, PDB/NCBI, TriTrypDB and ParameciumDB, respectively). Phospholipase $C$ of Paramecium tetraurelia is described in Klöppel et al., 2009 [27]. (1) Putative protein; (2) -like proteins; (3) encoded by pseudogene; (4) Leondaritis et al. (2013) [28], described 62 highly homologous phosphoinositide kinases genes; *genes that could not be found in databases.

\begin{tabular}{|c|c|c|c|c|c|c|}
\hline & $\begin{array}{c}\text { Phosphatidyl } \\
\text { Inositol 4-kinase }\end{array}$ & $\begin{array}{c}\text { Phosphatidyl } \\
\text { Inositol 4-phosphate } \\
\text { 5-kinase }\end{array}$ & Phospholipase C & $\begin{array}{c}\text { Inositol } \\
\text { Polyphosphate } \\
\text { 5-phosphatase }\end{array}$ & $\begin{array}{c}\text { Inositol 1,4,5- } \\
\text { Trisphosphate } \\
\text { 3-kinase }\end{array}$ & $\begin{array}{c}\text { Inositol Triphos- } \\
\text { phate Receptor }\end{array}$ \\
\hline $\begin{array}{c}\text { Toxoplasma gondii } \\
\text { ME49 }\end{array}$ & TGME49_328200 & TGME49_245730 & TGME49_248830 & $*$ & $*$ & $*$ \\
\hline Homo sapiens & $\begin{array}{l}\text { AAA56839.1; } \\
\text { BAA21661.1 }\end{array}$ & CAD99242.1 & $\begin{array}{l}\text { AAA60112.1; } \\
\text { BAA07688.1 }\end{array}$ & $\begin{array}{l}\text { CAA74743.1; } \\
\text { CAA67071.1 }\end{array}$ & $\begin{array}{l}\text { AAH26331.1; } \\
\text { CAC40650.1 }\end{array}$ & NP_002214.2 \\
\hline $\begin{array}{c}\text { Leishmania major } \\
\text { Friedlin }\end{array}$ & $\begin{array}{l}\text { LmjF.34.3590 } \\
\text { LmjF.29.1450 }\end{array}$ & $\begin{array}{l}\text { LmjF.36.0370(2); } \\
\text { LmjF.34.3090(2); } \\
\text { LmjF.35.0560 }\end{array}$ & $\begin{array}{l}\text { LmjF.30.2950 } \\
\text { LmjF.22.1680 }\end{array}$ & $*$ & $*$ & LmjF.16.0280 ${ }^{(1)}$ \\
\hline $\begin{array}{c}\text { Paramecium } \\
\text { tetraurelia }\end{array}$ & XP_001346932.1 & $\begin{array}{l}\text { XP_001347030.1; } \\
\text { XP_001347013.1 }\end{array}$ & $\begin{array}{l}\text { XP_001432600.1; } \\
\text { XP_001426835.1 }\end{array}$ & $*$ & (4) & PTMB. $445 \mathrm{c}$ \\
\hline
\end{tabular}

shows some important PI specific enzymes that have been reported in Apicomplexa and other unicellular parasites. The pathway by which PI is generated appears conserved amongst all eukaryotes [13]. The genes encoding the enzyme phosphatidylinositol synthase that catalyzes the formation of phosphatidylinositol (PI) are well characterized in P. falciparum and P. knowlesi [14], T. gondii [15] and T. brucei [16]. Phosphatidylinositol transfer protein encoding genes are also present, suggesting the existence of systems responsible for transporting PI from the ER to the plasmamembrane [1]. In Plasmodium, Gardner et al., 2002 [17] reported a gene encoding the enzyme phosphatidylinositol 4-kinase (PI4K) that catalyses the formation of phosphatidylinositol 4-phosphate (PIP) from phosphatidylinositol (PI). Thus, apicomplexans have the machinery to generate the precursor of $\mathrm{InsP}_{3}$. Table 1 summarizes known and putative proteins from the $\mathrm{InsP}_{3}$ pathway in model organisms and parasites. In mammalian systems the ability of $\mathrm{InsP}_{3}$ to act as a second messenger requires the enzymes to rapidly release $\mathrm{InsP}_{3}$ from $\mathrm{PIP}_{2}$, as well as the ability to reduce $\mathrm{InsP}_{3}$ levels to basal. Importantly, genetic evidence for phospholipase $\mathrm{C}$ enzymes can be found in all apicomplexans, except Sacrocysis (presumable due to a lack of genetic data), and Kinetoplastids (See Table 1). The presence of the archetypal PLC $\delta$ isoform in all genomes indicates the ability to generate $\mathrm{InsP}_{3}$ and $\mathrm{DAG}$ in unicellular parasites arising from a common ancestor. The enzymes involved in $\mathrm{InsP}_{3}$ metabolism are less well conserved. Plasmodium falciparum have an annotated inositol polyphosphate 5-phosphatase, an indication that they too can metabolize $\operatorname{InsP}_{3}$, to $\mathrm{InsP}_{2}$, whilst a specific inositol $1,4,5$ trisphosphate 3-kinase has not been annotated. However, inositol polyphosphate kinase genes can be found in both $P$. falciparum and $T$. gondii genomes and may metabolize $\operatorname{InsP}_{3}$ to $\mathrm{InsP}_{4}$.

\section{PHARMACOLOGICAL EVIDENCE FOR INSP SIGNALING IN APICOMPLEXA}

Importantly, biochemical evidence to support PI turnover in apicomplexan parasites has also been reported in the literature. Despite the fact that mammalian RBCs have all the enzymes enabling the production of $\mathrm{PIP}_{2}$ from PI [18], a noninfected RBC has limited biosynthesis of $\mathrm{PIP}_{2}$ and other PIs [19]; in contrast, when a RBC is infected with Plasmodium knowlesi; P falciparum, [20] and Babesia bovis [21] PI turnover increases due parasite metabolism. Incubating red blood cells (RBC) infected with $P$. falciparum with radiolabeled myo-inositol [22] results in the biosynthesis of PI, PIP and $\mathrm{PIP}_{2}$. Moreover, treatment with the $\mathrm{Ca}^{2+}$ ionophore, ionomycin, caused an increase in inositol phosphate production with Ins $1,4,5 \mathrm{P}_{3}$ levels being the highest. The increase of intracellular $\mathrm{Ca}^{2+}$ promoted by ionomycin presumably activates the $\mathrm{Ca}^{2+}$ sensitive PLC [23] to cleave $\mathrm{PIP}_{2}$, thus generating $\mathrm{InsP}_{3}$. Martin et al. [24] demonstrated the formation of $\mathrm{InsP}_{3}$ and diacylglycerol (DAG) during exflagellation of $P$. falciparum gametocytes, an important event in the sexual cycle that takes place in the Anopheles mosquitos. Fang et al.,[25] identified a PI-PLC $\delta$ in T. gondii that cleaves PIP . Whilst $_{2}$ recent bioinformatic approaches have failed to identify intracellular $\mathrm{Ca}^{2+}$ release channels such as $\mathrm{IP}_{3} \mathrm{Rs}$ and Ryanodine receptors (RyRs) within the genomes of apicomplexans [7, 26-28], a large body of pharmacological evidence suggests that a $\mathrm{Ca}^{2+}$ release channel sensitive to $\mathrm{InsP}_{3}$ does indeed 
exist in these species. Prompted by evidence that malaria parasites maintain intracellular $\mathrm{Ca}^{2+}$ stores, Passos et al. [29] published the first work demonstrating $\mathrm{InsP}_{3}$ mobilized $\mathrm{Ca}^{2+}$ from an intracellular store in $P$. chabaudi using a permeabilized cell system. The response was blocked by heparin (an inhibitor of $\mathrm{InsP}_{3} \mathrm{Rs}$ ) providing pharmacological evidence for an $\mathrm{InsP}_{3}$ dependent $\mathrm{Ca}^{2+}$ channel in P. chabaudi. Similarly, treatment of microsome preparations from $T$. gondii tachyzoites with $\mathrm{InsP}_{3}$ initiated $\mathrm{Ca}^{2+}$ release which could be fully blocked by pharmacological inhibitors of $\mathrm{InsP}_{3} \mathrm{Rs}$ (Xestospongin $\mathrm{C}$ and heparin) [30].

Inhibitors of the $\operatorname{Ins}_{3}$ signaling pathway, including agents that block Ins $\mathrm{P}_{3} \mathrm{R}$, such as heparin, xestospogin $\mathrm{C}$ and 2-aminoethoxydiphenyl borinate (2-APB), as well as inhibitors of PLC, such as U73122, have also been used to study $\mathrm{Ca}^{2+}$ signaling in Apicomplexa [31]. In T. gondii, the release of adhesins that mediate parasite attachment to host cells is an event regulated by $\mathrm{Ca}^{2+}$-mediated microneme secretion $[32,33]$. Lovett et al., (2002) also reported that T. gondii mobilizes $\mathrm{Ca}^{2+}$ when exposed to ryanodine or caffeine, both RyR ligands [34]. Addition of xestospongin $\mathrm{C}$ inhibited the caffeine- or ethanol-induced increase of intracellular $\mathrm{Ca}^{2+}$, thus preventing microneme secretion in T. gondii [35], and suggesting a role for $\operatorname{Ins}_{3} \mathrm{R}$. In Paramecium this pathway controls stimulated trichocyst exocytosis, as found by energy-dispersive X-ray microanalysis and fluorochrome analysis [36], via activation of RyR-type $\mathrm{Ca}^{2+}$ release channels in alveolar sacs [10,37]. RyRs share common features and an evolutionary history with $\operatorname{InsP}_{3} \mathrm{Rs}[9,38,39]$, yet RyRs are activated by the intracellular messenger cADPR (cyclic ADP-ribose) [40]. In fact, cADPR has been shown to activate $\mathrm{Ca}^{2+}$ signaling pathways in $T$. gondii and $P$. falciparum [30,41].

In malaria melatonin dependent signaling via calcium is well established $[29,42,43]$ enabling the investigation of a natural ligand to induce intracellular signaling. Hotta et al., [42] reported that intracellular $\mathrm{Ca}^{2+}$ mobilization induced by melatonin in P. falciparum and $P$. chabaudi is abolished by the PLC inhibitor U73122, but not by its inactive analogue, indicating that melatonin may activate signaling via PLC/InsP ${ }_{3}$. Enomoto et al., [44] blocked spontaneous $\mathrm{Ca}^{2+}$ mobilization in the ring and trophozoite forms of intraerythrocytic stage of $P$. falciparum using the $\mathrm{Ins}_{3} \mathrm{R}$ inhibitor, 2APB [45]. The presence of 2-APB during intraerythrocytic development of $P$. falciparum compromised the asexual replication of this parasite suggesting that blocking the $\operatorname{InsP}_{3} \mathrm{R}$ can be a potential target for antimalarial treatment. Raabe et al., [46] investigated the role of $\mathrm{PLP}_{2} / \mathrm{PLC} / \mathrm{InsP}_{3}$ during $P$. berghei gametocyte exflagellation induced by xanthurenic acid (XA), a small metabolic intermediate found in Anopheles mosquito gut. Under XA stimulus, addition of the PLC inhibitor U73122 inhibits $\mathrm{Ca}^{2+}$ mobilization in this model. Together this work suggested a vital role of the $\mathrm{InsP}_{3} / \mathrm{PLC}$ signaling pathway at different points during the Plasmodium life cycle, and the important nature of this pathway suggests it may contain potential antimalarial targets expressed during all life cycle phases.

Evidence for a ryanodine sensitive store in T. gondii [35] motivated Raabe et al., [46] to investigate the role of $\mathrm{Ca}^{2+}$ release via the RyR in $P$. berghei during gametocyte matura- tion. In the presence of RyR inhibitors, dantrolene and ruthenium red (RR), XA mediated $\mathrm{Ca}^{2+}$ increases were attenuated. Remarkably, RR treatment decreased $\mathrm{InsP}_{3}$ levels and dantrolene inhibited gametocyte maturation during $\mathrm{XA}$ stimulation. These data also suggest the existence of ryanodine sensitive channels in $P$. berghei. The development of cell permeant caged Ins $1,4,5 \mathrm{P}_{3},[47]$, enabled the investigation of $\mathrm{InsP}_{3}$ dependent calcium signaling without compromising membrane integrity. With this tool, Alves et al. [43] reported that $P$. falciparum trophozoites within intact $\mathrm{RBCs}$ release $\mathrm{Ca}^{2+}$ from thapsigargin-sensitive stores due to liberation of caged Ins $1,4,5 \mathrm{P}_{3}$. This observation was the first demonstration of a $\mathrm{Ca}^{2+}$-increase induced by exogenous $\mathrm{InsP}_{3}$ under physiological conditions in Apicomplexa. Furthermore, the authors reported an increase of $\mathrm{InsP}_{3}$ in infected $\mathrm{RBC}$ treated with melatonin. These data further support the concept of $\mathrm{PIP}_{2}$ hydrolysis to $\mathrm{InsP}_{3}$ as a signaling pathway activated by melatonin in $P$. falciparum, as reported previously $[42,48]$.

Mossaad et al. [49] first reported a complete reversal of chloroquine resistance in malaria parasites after treatment with 2-APB in vitro and in vivo, and this effect was justified by disturbance of $\mathrm{Ca}^{2+}$ homeostasis in the parasite cell. This result showed that 2 -APB and other related compounds that block the $\mathrm{InsP}_{3}$ pathway might be promising candidates in the search for new-resistance reversing agents that aid in treatment of the disease.

Beraldo et al. [50] showed that increase in cytosolic $\mathrm{Ca}^{2+}$ concentration in melatonin induced $P$. falciparum is abolished with the use of 2-APB, U73122 (PLC inhibitor) and luzindole (a melatonin antagonist). In the same work, capacitative calcium entry was also reported in malaria parasites.

Since then, other pharmacological agents have further been applied to investigate this pathway. It should be noted that most drugs used to interfere with signaling in protozoa are used solely on the basis of effects observed in mammalian cells [31], and all these drugs have potential off target effects. Despite this caveat, the combined evidence of a number of studies suggest the presence of an $\operatorname{Ins}_{3} \mathrm{R}$ and/or RYR calcium release channels in Plasmodia and Toxoplasma.

\section{INSP I $_{3}$ AND RYRS IN PROTOZOANS}

The history of $\mathrm{InsP}_{3} \mathrm{R}$ discovery and the impact of this receptor on mammalian cell signaling has been previously reviewed [51]. Knowledge of receptor sequences and functional proprieties in mammals, together with increasing information and access to genome databases for different organisms, made bioinformatics tools such as BLAST searches a major strategy to identify orthologs to putative $\operatorname{Ins}_{3} \mathrm{R}$ and RyRs in metazoans.

Until recently no information about such channels has been available from protozoa. After successful identification of $\mathrm{InsP}_{3} \mathrm{Rs}$ and RyR-like proteins $[9,37,52]$ in the ciliated protozoan, Paramecium, partial sequences suggested the occurrence of Ins $_{3} \mathrm{Rs}$ in several protozoan phyla, including trypanosomatids [37,39]. Similarity with established $\mathrm{InsP}_{3} \mathrm{Rs}$ is often scattered throughout the protein, with highest similarity in the carboxy-terminal region containing the pore do- 
main. Prole and Taylor [53] also used conserved regions of Ins $\mathrm{P}_{3} \mathrm{R}$ and $\mathrm{RyR}$, specifically the amino-terminal RIH (RyR and $\mathrm{InsP}_{3} \mathrm{R}$ homology) domain and the $\mathrm{N}$-terminal $\mathrm{InsP}_{3}$ binding domain, to successfully identify candidates for $\mathrm{InsP}_{3} \mathrm{R}$ in $T$. cruzi and $T$. brucei. Such work supported the identification of an $\mathrm{InsP}_{3} \mathrm{R}$-type protein in $T$. cruzi $[54,55]$ and T. brucei [56]. Hashimoto et al. [54] demonstrated that $\operatorname{TcIns} P_{3} R$ is essential for $T$. cruzi epimastigote survival, contributes to parasite invasiveness in mammalian cells, mediates $\mathrm{Ca}^{2+}$ release in trypomastigotes upon attachment to host cells, modulates parasite development and contributes to parasite virulence. These findings are consistent with previous evidence for a $\mathrm{InsP}_{3} / \mathrm{DAG}$ pathway in $T$. cruzi (49) and $T$ brucei [47].

The identification of an $\operatorname{InsP}_{3} \mathrm{R}$ candidate in apicomplexan parasites is a much more challenging task. When the same sequences of mammalian $\mathrm{InsP}_{3} \mathrm{Rs}$ were used for BLAST searches, no $\operatorname{InsP}_{3} \mathrm{R}$ orthologs were identified for Plasmodium, Toxoplasma, Cryptosporidium or Babesia species [53]. Previously, Naganume et al. [58], using a collection of $\mathrm{Ca}^{2+}$-associated protein orthologs to identify proteins participating in $\mathrm{Ca}^{2+}$ signaling, were also unable to find either any orthologs of $\operatorname{InsP}_{3} \mathrm{Rs}$, or of protein kinase $\mathrm{C}(\mathrm{PKC})$, a classic target for DAG activation [59]. Ladenburger et al., (2009) [37] were also unable to detect any $\operatorname{InsP}_{3} \mathrm{R}$ or RyR orthologs in genomes of apicomplexans, in contrast to ciliates where they are readily found.

Recently, it was reported that, when $\operatorname{TcIns} P_{3} R$ expression is decreased by two thirds compared to wildtype, the invasion of trypomastigotes of $T$. cruzi is blocked, indicating $\operatorname{TcIns} P_{3} R$ as a potential therapeutic target [60]. After treatment of trypomastigotes with specific antisense oligonucleotides of $T c \operatorname{Ins} P_{3} R$, a reduction in infectivity, thus suggesting that the suppression of transcription of this gene led to reduced levels of $T c I n s P_{3} R$ protein. In Chagas disease, $\mathrm{Ca}^{2+}$ signaling mediated by $\operatorname{Ins}_{3} \mathrm{R}$ plays a key role in multiple parasite differentiation steps [61]. A therapeutic approach using antisense transcripts is particularly feasible in the acute phase of infection in which trypomastigotes predominate in the bloodstream. It is possible that a treatment with antisense transcripts is effective in preventing the development of the disease by blocking the proliferation of trypomastigotes by inhibition of production of $\mathrm{TcInsP}_{3} \mathrm{R}$ [62].

The presence of dense mitochondria in T. cruzi with nonfunctional $\mathrm{InsP}_{3} \mathrm{R}$ provides new insights for the contribution of InsP ${ }_{3} \mathrm{Rs}$ to organelle integrity and the fact that 2-APB does not completely inhibit the development of trypomastigotes [63] suggest structural difference to mammalian $\mathrm{InsP}_{3} \mathrm{Rs}$ [64]. On the other hand, at high concentrations, 2APB might influence functions of proteins other than InsP ${ }_{3}$ Rs.

\section{LESSONS FROM OTHER SYSTEMS}

Clues about the composition of $\mathrm{Ca}^{2+}$ signaling pathways in apicomplexans can be drawn from their closest ancestral group, free living ciliates. It is estimated that ciliates originated between $\sim 800$ and 850 million years $[65,66]$. Apicomplexa are assumed to have arisen $\sim 550$, and the genus Plasmodium $\sim 400$ million years ago [65]. These events occurred much before Apicomplexa became parasites of vertebrates and then of mammalian species, which occurred only $\sim 13$ million years ago [67]. Paramecium tetraurelia contains several genes encoding Ins $\mathrm{P}_{3} \mathrm{Rs}$ and RyR-like channels that have been identified at a genomic and proteomic level $[9,37,52]$. Considering the finding of $\mathrm{InsP}_{3} \mathrm{Rs}$ and of RyRlike channels in Paramecium [10], the argument that the old age of some phyla may explain the failure to detect $\mathrm{Ca}^{2+}$ release channels in apicomplexans appears unlikely.

The lack of conservation at the gene level, suggests that Ins $\mathrm{P}_{3} \mathrm{R}$ in apicomplexans may diverge significantly from mammalian channels and those found in ciliates; one may ask whether they adopted a different, distinct protein or a complex of proteins for $\operatorname{Ins}_{3} \mathrm{R}$ function. If this is the case, successful identification of $\operatorname{Ins}_{3} \mathrm{R}$ in apicomplexans may require a different strategy focused on biochemical and physiological criteria. Specifically one should consider that any $\mathrm{Ca}^{2+}$ release channel requires a pore domain with six transmembrane stretches in $\operatorname{Ins}_{3} \mathrm{Rs}$ and RyRs, from ciliates to humans, and a rather conserved, though slightly variable selectivity filter [10].

Currently the lack of identified $\mathrm{Ca}^{2+}$ release channels in Apicomplexa leaves a significant gap in our understanding of PI and calcium signaling mechanisms. There are clear physiological effects of stimulating production of $\mathrm{InsP}_{3}$, and of inhibiting putative channels, and yet the molecular machinery in Apicomplexa is clearly diverse from other cells. Ultrastructurally the inner membrane complex of Apicomplexa looks very much like the alveolar sacs of ciliates; however, whereas the sacs of ciliates are well established $\mathrm{Ca}^{2+}$ stores [36], they appear largely independent of such function in Apicomplexa [8]. The third enigma is the presence of well defined $\mathrm{InsP}_{3} \mathrm{R}$ - and RyR-type $\mathrm{Ca}^{2+}$ release channels in ciliates $[9,37,52]$, in contrast to their absence in their closest relatives, the Apicomplexa [68,69].

Similar to apicomplexans, plant genomes lack recognizable $\mathrm{InsP}_{3} \mathrm{Rs}$ in despite of evidence for an $\mathrm{InsP}_{3}$ signaling pathway [70]. Despite responding to $\mathrm{InsP}_{3}$ to regulate $\mathrm{Ca}^{2+}$ increases, land plants typically lack an $\mathrm{InsP}_{3} \mathrm{R}$ or RyR, leading to the suggestion that these channels were animalspecific, and perhaps evolved during the vertebrate lineage [70]. However, recent evidence from green algae Chlamydomonas indicates that chlorophyte plants contain $\operatorname{InsP}_{3} \mathrm{R}$, suggesting they were present in the ancestral eukaryotes prior to the plant-animal split [71]. Why $\operatorname{InsP}_{3} \mathrm{R}$ channels appear to have been lost in land plants remains a mystery, but it is intriguing to consider that like apicomplexans, they may have evolved different mechanism to release internal $\mathrm{Ca}^{2+}$ stores in response to $\mathrm{InsP}_{3}$.

\section{CONCLUSION}

Differences in $\mathrm{Ca}^{2+}$ signaling between parasites and their hosts may present unique targets for developing interventions. For example, McNamara et al., 2013 [72] reported PI4K as a target of imidazopyrazine, a class of new antimalarial drug that inhibits all stages of malaria parasite infection of the vertebrate host and also prevents transmission by mosquitos to a murine malaria model. Additionally, as mentioned above, agents that disrupt $\operatorname{InsP}_{3} \mathrm{R}$ channels such as 2ABP block malaria growth in vitro [44]. Given the apparent 
divergent mechanism by which $\mathrm{InsP}_{3}$ is sensed in parasites, identification of the molecular basis for this pathway might also identify novel targets for intervention.

The pharmacological literature and functional studies with exogenous $\operatorname{InsP}_{3}$ discussed herein seem to support the occurrence of $\mathrm{InsP}_{3} \mathrm{R}$-type $\mathrm{Ca}^{2+}$-channels in ciliates, trypanosomatids and apicomplexans. Ins $\mathrm{P}_{3} \mathrm{R}$ is the major missing piece of the PI signaling puzzle in Apicomplexa. Although Ins $\mathrm{P}_{3} \mathrm{R}$ have been found in ciliates and tryponosomatids, the lack of ${ }^{3} \mathrm{H}-\mathrm{InsP}_{3}$ binding assays in parallel to a vast unknown protein function in apicomplexans genome has hampered the identification of potential candidates for $\operatorname{InsP}_{3} \mathrm{R}$. Although identification of these channels will certainly not be an easy task, it will be a rewarding engagement for groups willing to accept the challenge.

\section{CONSENT FOR PUBLICATION}

Not applicable.

\section{CONFLICT OF INTEREST}

The authors confirm that this article content has no conflict of interest.

\section{ACKNOWLEDGEMENTS}

Supported by São Paulo Research Foundation (Process number 2011/51295-5) to CRSG, by a grant from the National Institutes of Health, USA (AI094098) to LDS, AI099277 to APT and by grants from the German Research Council to H.P.

\section{REFERENCES}

[1] Balla, T. Phosphoinositides: tiny lipids with giant impact on cell regulation. Physiol. Rev., 2013, 93, 1019-1137.

[2] Michell, R.H. Inositol derivatives: evolution and functions. Nat. Rev. Mol. Cell Biol., 2008, 9(2), 151-161.

[3] Michell, R.H. Inositol phospholipids and cell surface receptor function. Biochim. Biophys. Acta - Rev. Biomembr., 1975, 415(1), 81-147.

[4] Fain, J.N.; Berridge, M.J. Relationship between phosphatidylinositol synthesis and recovery of 5-hydroxytryptamine-responsive $\mathrm{ca}^{2+}$ flux in blowfly salivary glands. Biochem. J., 1979, 180(3), 655-661.

[5] Streb, H.; Irvine, R.F.; Berridge, M.J.; Schulz, I. Release of $\mathrm{ca}^{2+}$ from a nonmitochondrial intracellular store in pancreatic acinar cells by inositol-1,4,5-trisphosphate. Nature, 1983, 306(5938), 6769 .

[6] Berridge, M.J.; Irvine, R.F. Inositol trisphosphate, a novel second messenger in cellular signal transduction. Nature, 1984, 312(5992), 315-321.

[7] Lourido, S.; Moreno, S.N.J. The calcium signaling toolkit of the apicomplexan parasites toxoplasma gondii and plasmodium spp. Cell Calcium, 2014, 57(3), 186-193.

[8] Plattner, H.; Sehring, I.M.; Mohamed, I.K.; Miranda, K.; De Souza, W.; Billington, R.; Genazzani, A.; Ladenburger, E.M. Calcium signaling in closely related protozoan groups(alveolata): nonparasitic ciliates(paramecium, tetrahymena) vs. parasitic apicomplexa(plasmodium, toxoplasma). Cell Calcium, 2012, 51, 351-382.

[9] Ladenburger, E.-M.; Plattner, H. Calcium-release channels in paramecium. genomic expansion, differential positioning and partial transcriptional elimination. PLoS One, 2011, 6(11), e27111.

[10] Plattner, H. Molecular aspects of calcium signalling at the crossroads of unikont and bikont eukaryote evolution - the ciliated protozoan paramecium in focus. Cell Calcium, 2014, 57(3), 174185.
[11] Borges-Pereira, L.; Campos, B.R.K.L.; Garcia, C.R.S. The GCaMP3 - A GFP-based calcium sensor for imaging calcium dynamics in the human malaria parasite plasmodium falciparum. MethodsX, 2014, 1, 151-154.

[12] Borges-Pereira, L.; Budu, A.; McKnight, C.A.; Moore, C.A.; Vella, S.A.; Hortua Triana, M.A.; Liu, J.; Garcia, C.R. S.; Pace, D.A.; Moreno, S.N.J. Calcium signaling throughout the toxoplasma gondii lytic cycle. a study using genetically encoded calcium indicators. J. Biol. Chem., 2015, 3, jbc.M115.652511.

[13] Michell, R.H. Inositol and its derivatives: their evolution and functions. Adv. Enzyme Regul., 2011, 51(1), 84-90.

[14] Wengelnik, K.; Vial, H.J. Characterisation of the phosphatidylinositol synthase gene of plasmodium species. Res. Microbiol., 2007, 158, 51-59.

[15] Séron, K.; Dzierszinski, F.; Tomavo, S. Molecular cloning, functional complementation in saccharomyces cerevisiae and enzymatic properties of phosphatidylinositol synthase from the protozoan parasite toxoplasma gondii. Eur. J. Biochem., 2000, 267(22), 6571-6579.

[16] Martin, K.L.; Smith, T.K. Phosphatidylinositol synthesis is essential in bloodstream form trypanosoma brucei. Biochem. J., 2006, 396(2), 287-295

[17] Gardner, M.J.; Hall, N.; Fung, E.; White, O.; Berriman, M.; Hyman, R.W.; Carlton, J.M.; Pain, A.; Nelson, K.E.; Bowman, S.; Paulsen, I.T.; James, K.; Eisen, J.A.; Rutherford, K.; Salzberg, S.L.; Craig, A.; Kyes, S.; Chan, M.-S.; Nene, V.; Shallom, S.J.; Suh, B.; Peterson, J.; Angiuoli, S.; Pertea, M.; Allen, J.; Selengut, J.; Haft, D.; Mather, M.W.; Vaidya, A.B.; Martin, D.M. A.; Fairlamb, A.H.; Fraunholz, M.J.; Roos, D.S.; Ralph, S.A.; McFadden, G.I.; Cummings, L.M.; Subramanian, G.M.; Mungall, C.; Venter, J.C.; Carucci, D.J.; Hoffman, S.L.; Newbold, C.; Davis, R.W.; Fraser, C.M.; Barrell, B. Genome sequence of the human malaria parasite plasmodium falciparum. Nature, 2002, 419(6906), 498-511.

[18] Allan, D. Inositol lipids and membrane function in erythrocytes. Cell Calcium, 1982, 3(4-5), 451-465.

[19] van Deenen, L.L. M.; de Gier, J.; Demel, R.A.; de Kruyff, B.; Blok, M.C.; van der Neut-Kok, E.C. M.; Haest, C.W. M.; Ververgaert, P.H. J.T.; Verkleij, A.J. Lipid-lipid and lipid-protein interaction in model systems and membranes. Ann. N. Y. Acad. Sci., 1975, 264(1), 124-141.

[20] Vial, H.J.; Ancelin, M.L.; Philippot, J.R.; Thuet, M.J. Biosynthesis and dynamics of lipids in plasmodium-infected mature mammalian erythrocytes. Blood Cells, 1990, 16, 531-555.

[21] Florin-Christensen, J.; Suarez, C.E.; Florin-Christensen, M.; Hines, S.A.; McElwain, T.F.; Palmer, G.H. Phosphatidylcholine formation is the predominant lipid biosynthetic event in the hemoparasite babesia bovis. Mol. Biochem. Parasitol., 2000, 106(1), 147-156.

[22] Elabbadi, N.; Ancelin, M.L.; Vial, H.J. Characterization of phosphatidylinositol synthase and evidence of a polyphosphoinositide cycle in plasmodium-infected erythrocytes. Mol Biochem Parasitol, 1994, 63(2), 179-192.

[23] Abdel-Latif, A.A. Calcium-mobilizing receptors, polyphosphoinositides, generation of second messengers and contraction in the mammalian iris smooth muscle: historical perspectives and current status. Life Sci., 1989, 45(9), 757-786.

[24] Martin, S.K.; Jett, M.; Schneider, I. Correlation of phosphoinositide hydrolysis with exflagellation in the malaria microgametocyte. $J$. Parasitol., 1994, 80(3), 371-378.

[25] Fang, J.; Marchesini, N.; Moreno, S.N.J. A Toxoplasma gondii phosphoinositide phospholipase c(tgpi-plc) with high affinity for phosphatidylinositol. Biochem. J., 2006, 394(Pt 2), 417-425.

[26] Moreno, S.N. J.; Ayong, L.; Pace, D.A. Calcium storage and function in apicomplexan parasites. Essays Biochem., 2011, 51, 97110 .

[27] Klöppel, C.; Müller, A.; Marker, S.; Simon, M. Two isoforms of eukaryotic phospholipase $\mathrm{c}$ in paramecium affecting transport and release of gpi-anchored proteins in vivo. Eur. J. Cell Biol., 2009, $88(10), 577-592$

[28] Leondaritis, G.; Siokos, J.; Skaripa, I.; Galanopoulou, D. GenomeWide analysis of the phosphoinositide kinome from two ciliates reveals novel evolutionary links for phosphoinositide kinases in eukaryotic cells. PLoS One, 2013, 8(11).

[29] Passos, A.P.; Garcia, C.R. Inositol 1,4,5-trisphosphate induced $\mathrm{ca}^{2+}$ release from chloroquine-sensitive and -insensitive intracellular stores in the intraerythrocytic stage of the malaria parasite $p$. 
chabaudi. Biochem. Biophys. Res. Commun., 1998, 245(1), 155160.

[30] Chini, E.N.; Nagamune, K.; Wetzel, D.M.; Sibley, L.D. Evidence that the cadpr signalling pathway controls calcium-mediated microneme secretion in toxoplasma gondii. Biochem. J., 2005, 389(Pt 2), 269-277.

[31] Cruz, L.N.; Guerra, M.T.; Kruglov, E.; Mennone, A.; Garcia, C.R. S.; Chen, J.; Nathanson, M.H. Regulation of multidrug resistanceassociated protein 2 by calcium signaling in mouse liver. Hepatology, 2010, 52(1), 327-337.

[32] Carruthers, V.B.; Giddings, O.K.; Sibley, L.D. Secretion of Micronemal Proteins Is Associated with Toxoplasma Invasion of Host Cells. Cell. Microbiol., 1999, 1(3), 225-235.

[33] Vieira, M.C. F.; Moreno, S.N. J. Mobilization of intracellular calcium upon attachment of toxoplasma gondii tachyzoites to human fibroblasts is required for invasion. Mol. Biochem. Parasitol., 2000, 106(1), 157-162.

[34] Zucchi, R.; Ronca-Testoni, S. The sarcoplasmic reticulum $\mathrm{ca}^{2+}$ channel/ryanodine receptor: modulation by endogenous effectors, drugs and disease states . Pharmacol. Rev. , 1997, 49(1), 1-52.

[35] Lovett, J.L.; Marchesini, N.; Moreno, S.N. J.; Sibley, L.D. Toxoplasma gondii microneme secretion involves intracellular $\mathrm{ca}^{2+}$ release from inositol 1,4,5-triphosphate(ip(3))/ryanodine-sensitive stores. J. Biol. Chem., 2002, 277(29), 25870-25876.

[36] Plattner, H. Calcium regulation in the protozoan model, paramecium tetraurelia. J. Eukaryot. Microbiol., 2014, 61, 95-114.

[37] Ladenburger, E.-M.; Sehring, I.M.; Korn, I.; Plattner, H. Novel Types of $\mathrm{Ca}^{2+}$ Release channels participate in the secretory cycle of paramecium cells. Mol. Cell. Biol., 2009, 29(13), 3605-3622.

[38] Mackrill, J.J. Ryanodine receptor calcium release channels: an evolutionary perspective. Adv Exp Med Biol, 2012, 740, 159-182.

[39] Plattner, H.; Verkhratsky, A. $\mathrm{Ca}^{2+}$ signalling early in evolution--all but primitive. J. Cell Sci., 2013, 126(Pt 10), 2141-2150.

[40] Lee, H.C. Cyclic adp-ribose and nicotinic acid adenine dinucleotide phosphate(naadp) as messengers for calcium mobilization. J. Biol. Chem., 2012, 287(38), 31633-31640.

[41] Jones, M.L.; Cottingham, C.; Rayner, J.C. Effects of calcium signaling on plasmodium falciparum erythrocyte invasion and posttranslational modification of gliding-associated protein 45(pfgap45). Mol. Biochem. Parasitol., 2009, 168(1), 55-62.

[42] Hotta, C.T.; Gazarini, M.L.; Beraldo, F.H.; Varotti, F.P.; Lopes, C.; Markus, R.P.; Pozzan, T.; Garcia, C.R. S. Calcium-dependent modulation by melatonin of the circadian rhythm in malarial parasites. Nat. Cell Biol., 2000, 2(7), 466-468.

[43] Alves, E.; Bartlett, P.J.; Garcia, C.R. S.; Thomas, A.P. Melatonin and ip3-induced $\mathrm{ca}^{2+}$ release from intracellular stores in the malaria parasite plasmodium falciparum within infected red blood cells. $J$. Biol. Chem., 2011, 286(7), 5905-5912.

[44] Enomoto, M.; Kawazu, S.; Kawai, S.; Furuyama, W.; Ikegami, T.; Watanabe, J.; Mikoshiba, K. Blockage of spontaneous $\mathrm{ca}^{2+}$ oscillation causes cell death in intraerythrocitic plasmodium falciparum. PLoS One, 2012, 7(7), e39499.

[45] Maruyama, T.; Kanaji, T.; Nakade, S.; Kanno, T.; Mikoshiba, K. 2APB, 2-aminoethoxydiphenyl borate, a membrane-penetrable modulator of ins $(1,4,5) \mathrm{p}_{3}$-induced $\mathrm{ca}^{2+}$ release. J. Biochem., 1997, 122(3), 498-505

[46] Raabe, A.C.; Wengelnik, K.; Billker, O.; Vial, H.J. Multiple roles for plasmodium berghei phosphoinositide-specific phospholipase c in regulating gametocyte activation and differentiation. Cell. Microbiol., 2011, 13(7), 955-966.

[47] Dakin, K.; Li, W.-H. Cell membrane permeable esters of d-myoinositol 1,4,5-trisphosphate. Cell Calcium, 2007, 42(3), 291-301.

[48] Beraldo, F.H.; Almeida, F.M.; Da Silva, A.M.; Garcia, C.R. S. Cyclic AMP and calcium interplay as second messengers in melatonin-dependent regulation of plasmodium falciparum cell cycle. J. Cell Biol., 2005, 170(4), 551-557.

[49] Mossaad, E.; Furuyama, W.; Enomoto, M.; Kawai, S.; Mikoshiba, K.; Kawazu, S. Simultaneous Administration of 2-aminoethyl diphenylborinate and chloroquine reverses chloroquine resistance in malaria parasites. Antimicrob. Agents Chemother., 2015, 59(5), 2890-2892.

[50] Beraldo, F.H.; Mikoshiba, K.; Garcia, C.R. S. Human malarial parasite, plasmodium falciparum, displays capacitative calcium entry: 2-aminoethyl diphenylborinate blocks the signal transduction pathway of melatonin action on the p. falciparum cell cycle. $J$. Pineal Res., 2007, 43(4), 360-364.
[51] Mikoshiba, K. IP3 receptor/ $\mathrm{Ca}^{2+}$ Channel: from discovery to new signaling concepts. J. Neurochem., 2007, 102(5), 1426-1446.

[52] Ladenburger, E.-M.; Korn, I.; Kasielke, N.; Wassmer, T.; Plattner, H. An ins $(1,4,5) \mathrm{p} 3$ receptor in paramecium is associated with the osmoregulatory system. J. Cell Sci., 2006, 119(Pt 17), 3705-3717.

[53] Prole, D.L.; Taylor, C.W. Identification of Intracellular and Plasma Membrane Calcium Channel Homologues in Pathogenic Parasites. PLoS One, 2011, 6(10), e26218.

[54] Hashimoto, M.; Enomoto, M.; Morales, J.; Kurebayashi, N.; Sakurai, T.; Hashimoto, T.; Nara, T.; Mikoshiba, K. Inositol 1,4,5trisphosphate receptor regulates replication, differentiation, infectivity and virulence of the parasitic protist Trypanosoma Cruzi. Mol. Microbiol., 2013, 87(6), 1133-1150.

[55] Ulrich, P.N.; Jimenez, V.; Park, M.; Martins, V.P.; Atwood, J.; Moles, K.; Collins, D.; Rohloff, P.; Tarleton, R.; Moreno, S.N. J.; Orlando, R.; Docampo, R. Identification of contractile vacuole proteins in Trypanosoma Cruzi. PLoS One, 2011, 6(3), e18013.

[56] Huang, G.; Bartlett, P.J.; Thomas, A.P.; Moreno, S.N. J.; Docampo, R. Acidocalcisomes of Trypanosoma Brucei have an inositol 1,4,5trisphosphate receptor that is required for growth and infectivity. Proc. Natl. Acad. Sci. U. S. A., 2013, 110(5), 1887-1892.

[57] Racagni, G.; García de Lema, M.; Domenech, C.E.; Machado de Domenech, E.E. Phospholipids in Trypanosoma Cruzi: Phosphoinositide Composition and Turnover. Lipids, 1992, 27(4), 275-278.

[58] Nagamune, K.; Sibley, L.D. Comparative genomic and phylogenetic analyses of calcium atpases and calcium-regulated proteins in the apicomplexa. Mol. Biol. Evol., 2006, 23(8), 16131627.

[59] Berridge, M.J.; Irvine, R.F. Inositol trisphosphate as a second messenger in signal transduction. Nature, 1987, 494, 39-51.

[60] Hashimoto, M.; Nara, T.; Hirawake, H.; Morales, J.; Enomoto, M.; Mikoshiba, K. Antisense oligonucleotides targeting parasite inositol 1,4,5-trisphosphate receptor inhibits mammalian host cell invasion by Trypanosoma Cruzi. Sci. Rep., 2014, 4, 4231.

[61] Hashimoto, M.; Morales, J.; Uemura, H.; Mikoshiba, K.; Nara, T. A Novel method for inducing amastigote-to-trypomastigote transformation in vitro in trypanosoma cruzi reveals the importance of inositol 1,4,5-trisphosphate receptor. PLoS One, 2015, 10(8), e0135726.

[62] Hashimoto, M.; Nara, T.; Mita, T.; Mikoshiba, K. Morpholino antisense oligo inhibits trans-splicing of pre-inositol 1,4,5trisphosphate receptor mrna of Trypanosoma Cruzi and suppresses parasite growth and infectivity. Parasitol. Int., 2015, 65(3), 175179.

[63] Hashimoto, M.; Nara, T.; Enomoto, M.; Kurebayashi, N.; Yoshida, M.; Sakurai, T.; Mita, T.; Mikoshiba, K. A dominant negative form of inositol 1,4,5-trisphosphate receptor induces metacyclogenesis and increases mitochondrial density in Trypanosoma Cruzi. Biochem. Biophys. Res. Commun., 2015, 466(3), 475-480.

[64] Yoshikawa, F.; Iwasaki, H.; Michikawa, T.; Furuichi, T.; Mikoshiba, K. Trypsinized cerebellar inositol 1,4,5-trisphosphate receptor: structural and functional coupling of cleaved ligand binding and channel domains. J. Biol. Chem., 1999, 274(1), 316327.

[65] Douzery, E.J. P.; Snell, E. a; Bapteste, E.; Delsuc, F.; Philippe, H. The Timing of eukaryotic evolution: does a relaxed molecular clock reconcile proteins and fossils? Proc. Natl. Acad. Sci. U. S. A., 2004, 101(43), 15386-15391.

[66] Parfrey, L.W.; Lahr, D.J. G.; Knoll, A.H.; Katz, L.A. Estimating the timing of early eukaryotic diversification with multigene molecular clocks. Proc. Natl. Acad. Sci. USA, 2011, 108(33), 13624-13629.

[67] Ricklefs, R.E.; Outlaw, D.C. A molecular clock for malaria parasites. Science, 2010, 329, 226-229.

[68] Aravind, L.; Iyer, L.M.; Wellems, T.E.; Miller, L.H. Plasmodium biology: genomic gleanings. Cell, 2003, 115(7), 771-785.

[69] Adl, S.M.; Simpson, A.G. B.; Lane, C.E.; Lukeš, J.; Bass, D.; Bowser, S.S.; Brown, M.W.; Burki, F.; Dunthorn, M.; Hampl, V.; Heiss, A.; Hoppenrath, M.; Lara, E.; Le Gall, L.; Lynn, D.H.; McManus, H.; Mitchell, E.A. D.; Mozley-Stanridge, S.E.; Parfrey, L.W.; Pawlowski, J.; Rueckert, S.; Shadwick, R.S.; Shadwick, L.; Schoch, C.L.; Smirnov, A.; Spiegel, F.W. The revised classification of eukaryotes. J. Eukaryot. Microbiol., 2012, 59(5), 429-493. 
[70] Krinke, O.; Novotná, Z.; Valentová, O.; Martinec, J. Inositol trisphosphate receptor in higher plants: is it real? J. Exp. Bot., 2007, 58(3), 361-376.

[71] Wheeler, G.L.; Brownlee, C. $\mathrm{Ca}^{2+}$ signalling in plants and green algae - changing channels. Trends Plant Sci., 2008, 13(9), 506-514.

[72] McNamara, C.W.; Lee, M.C. S.; Lim, C.S.; Lim, S.H.; Roland, J.; Nagle, A.; Simon, O.; Yeung, B.K. S.; Chatterjee, A.K.; McCormack, S.L.; Manary, M.J.; Zeeman, A.-M.; Dechering, K.J.; Kumar, T.R. S.; Henrich, P.P.; Gagaring, K.; Ibanez, M.; Kato, N.;
Kuhen, K.L.; Fischli, C.; Rottmann, M.; Plouffe, D.M.; Bursulaya, B.; Meister, S.; Rameh, L.; Trappe, J.; Haasen, D.; Timmerman, M.; Sauerwein, R.W.; Suwanarusk, R.; Russell, B.; Renia, L.; Nosten, F.; Tully, D.C.; Kocken, C.H. M.; Glynne, R.J.; Bodenreider, C.; Fidock, D. A; Diagana, T.T.; Winzeler, E.A Targeting plasmodium pi(4)k to eliminate malaria. Nature, 2013, 504(7479), 248-253. 